Meta

Journal des traducteurs

Translators' Journal

\title{
The Polymorphic Behaviour of Adjectives in Terminography
}

\section{Paula de Santiago González et Larisa Grcic Simeunovic}

Volume 62, numéro 1, avril 2017

URI : https://id.erudit.org/iderudit/1040473ar

DOI : https://doi.org/10.7202/1040473ar

Aller au sommaire du numéro

\section{Éditeur(s)}

Les Presses de l’Université de Montréal

ISSN

0026-0452 (imprimé)

1492-1421 (numérique)

Découvrir la revue

Citer cet article

de Santiago González, P. \& Grcic Simeunovic, L. (2017). The Polymorphic Behaviour of Adjectives in Terminography. Meta, 62(1), 201-222.

https://doi.org/10.7202/1040473ar

\section{Résumé de l'article}

Bien que les adjectifs fassent l'objet d'analyses approfondies par les terminologues, ils ne reçoivent encore que trop peu d'attention dans les diverses applications terminographiques. Le niveau de leur inclusion dans les bases de données terminologiques, par exemple, est faible par rapport aux noms. Cependant, en étudiant les langues de spécialité comme la karstologie, il est évident que les adjectifs jouent un rôle significatif dans le discours spécialisé en raison de leur comportement polymorphique. Notre étude montre qu'en fonction de leurs relations sémantiques et syntactiques avec d'autres unités lexicales, les adjectifs nous fournissent des informations précieuses pour la gestion terminologique et la formalisation conceptuelle. Du point de vue sémantique, les adjectifs mettent en évidence les attributs des objets dans la modélisation du domaine en permettant aux traducteurs de découvrir les concepts plus spécifiques ou les aspects différents des concepts déjà connus. Du point de vue syntaxique, les adjectifs établissent de nombreuses relations syntagmatiques avec des noms, en construisant des termes complexes ou des collocations. Alors que les premiers délimitent la signification du nom en construisant de nouvelles unités lexicales spécialisées, les deuxièmes révèlent l'usage des termes (complexes ou simples) en contexte. Cette étude est basée sur un corpus monolingue anglais portant sur la karstologie. Elle vise à étudier les propriétés fonctionnelles et représentationnelles des adjectifs épithètes dans le discours spécialisé et leur apport dans la structuration conceptuelle du domaine spécialisé.
Ce document est protégé par la loi sur le droit d'auteur. L’utilisation des services d'Érudit (y compris la reproduction) est assujettie à sa politique d'utilisation que vous pouvez consulter en ligne.

https://apropos.erudit.org/fr/usagers/politique-dutilisation/ 


\title{
The Polymorphic Behaviour of Adjectives in Terminography
}

\author{
PAULA DE SANTIAGO GONZÁLEZ \\ Universidad de Valladolid, Valladolid, Spain \\ desantiagopaula@gmail.com
}

\author{
LARISA GRCIC SIMEUNOVIC \\ University of Zadar, Zadar, Croatia \\ larisa.grcic@gmail.com
}

\section{RÉSUMÉ}

Bien que les adjectifs fassent l'objet d'analyses approfondies par les terminologues, ils ne reçoivent encore que trop peu d'attention dans les diverses applications terminographiques. Le niveau de leur inclusion dans les bases de données terminologiques, par exemple, est faible par rapport aux noms. Cependant, en étudiant les langues de spécialité comme la karstologie, il est évident que les adjectifs jouent un rôle significatif dans le discours spécialisé en raison de leur comportement polymorphique. Notre étude montre qu'en fonction de leurs relations sémantiques et syntactiques avec d'autres unités lexicales, les adjectifs nous fournissent des informations précieuses pour la gestion terminologique et la formalisation conceptuelle. Du point de vue sémantique, les adjectifs mettent en évidence les attributs des objets dans la modélisation du domaine en permettant aux traducteurs de découvrir les concepts plus spécifiques ou les aspects différents des concepts déjà connus. Du point de vue syntaxique, les adjectifs établissent de nombreuses relations syntagmatiques avec des noms, en construisant des termes complexes ou des collocations. Alors que les premiers délimitent la signification du nom en construisant de nouvelles unités lexicales spécialisées, les deuxièmes révèlent l'usage des termes (complexes ou simples) en contexte. Cette étude est basée sur un corpus monolingue anglais portant sur la karstologie. Elle vise à étudier les propriétés fonctionnelles et représentationnelles des adjectifs épithètes dans le discours spécialisé et leur apport dans la structuration conceptuelle du domaine spécialisé.

\begin{abstract}
Adjectives, while analyzed quite thoroughly in the works of terminologists, have not received enough attention in terminographic applications. Their inclusion, for instance in terminological databases, is low in comparison to that of nouns. However, the study of a specialized language such as karstology shows that adjectives have significant value due to their polymorphic behaviour. Our study shows that, depending on their semantic and syntactic relations with other lexical units, adjectives can provide us with essential information for terminology management and specialized knowledge organization. Semantically, adjectives highlight attributes of object concepts within a field allowing translators to discover more specific concepts, or different aspects of already known concepts. Syntactically, adjectives can present various syntagmatic relations with nouns. While some adjectives constrain the meaning of the noun, constructing other specific lexical units, others reveal the usage of terms (either complex or simple) in context. Our study, which is based on an analysis of a monolingual English corpus, has as its purpose to identify the most relevant attributive adjectives and explain their role in a specialized language such as karstology. We will also reflect on the presence of these adjectives in terminological dictionaries and on their contribution to the conceptual structure of a knowledge field.
\end{abstract}




\section{RESUMEN}

Aunque los adjetivos se han analizado detalladamente en estudios realizados por terminólogos, no han recibido demasiada atención en aplicaciones terminográficas. Su inclusión en bases de datos terminológicas es baja en comparación con la de los nombres. Sin embargo, el estudio de un lenguaje especializado como el de la karstología prueba que los adjetivos tienen un valor significativo debido a su comportamiento polimórfico. Nuestro estudio demuestra que los adjetivos, dependiendo de las relaciones semánticas y sintácticas con otras unidades léxicas, pueden revelar información esencial para la gestión terminológica y la organización conceptual de un campo especializado. Semánticamente, los adjetivos señalan los atributos de los conceptos de un campo permitiendo a los traductores descubrir más conceptos específicos o aspectos diferentes de conceptos ya conocidos. Sintácticamente, los adjetivos pueden presentar varias relaciones sintagmáticas con nombres. Mientras algunos adjetivos limitan el significado de los nombres, creando otras unidades léxicas más específicas, otros revelan el uso de los términos (compuestos o simples) en contexto. Nuestro estudio, basado en el análisis de un corpus monolingüe en lengua inglesa, tiene como objetivo identificar los adjetivos atributivos y explicar su papel en un lenguaje especializado, que en nuestro caso es el de la karstología. Además reflexionaremos también sobre los adjetivos en diccionarios terminológicos y sobre su contribución en la estructura conceptual del campo de conocimiento.

\section{MOTS-CLÉS/KEYWORDS/PALABRAS CLAVE}

adjectif, terminologie, linguistique de corpus, karstologie, représentation de connaissances adjective, terminology, corpus linguistics, karstology, knowledge representation adjetivo, terminología, lingüística del corpus, karstología, representación del conocimiento

\section{Adjectives in phrasal and compound noun constructions}

Previous studies (Lorente 2001; Alonso and Torner 2010) have shown that not only nouns but also verbs and adjectives can play a significant role in specialized languages. Like nouns, verbs and adjectives can acquire specialized meanings in specific domain contexts and, as such, they should have a prominent position in terminological dictionaries.

Among the influential works that have taken into account the adjective category, mention should be made of the methodology of encoding the synsets of definitional features applied in the lexical database Wordnet (Fellbaum et al. 1993; Miller 1998). This specific approach enlarged the perspective on the semantic nature of adjectives and their organization into classes using the cluster effect. While the creation of adjective classes can be based on the relations expressed in the Wordnet network (Mendes 2006), other models for defining classes of adjectives have been proposed according to different syntactic, semantic or pragmatic criteria (Marquez 1998). Previous research has also demonstrated that both the issues of adjectival polysemy and the dynamic construction of their meaning can be resolved by using distributional classes of adjectives (Venant 2007).

The present study relies especially on research regarding the adjective's definitional features in terminology structuring as well as their function within multiword units (Bouillon 1997; Sanfilippo et al. 1998; Bouillon and Viegas 1999; Normand and Bourigault 2001; L'Homme 2004; Carrière 2008). In particular, we have focused on the notion of polymorphy, which is defined by Bouillon (1997) as the capacity of words to appear in various morphological, syntactic and semantic contexts. The 
polymorphic behaviour of adjectives results from the differences found between the semantic types of adjectives and nouns and the different ways in which the two constituents are combined in multiword units.

According to Lyons (1977: 448), adjectives occur more "freely" than any other lexical category that modifies nouns, which might be the reason why they are able to vary in form, function and meaning (Sanfilippo et al. 1998). From our point of view, their polymorphic behaviour has made their inclusion in terminological dictionaries even more difficult. The different semantic and syntactic relations of adjectives with nouns have made terminologists doubt the unithood ${ }^{1}$ of multiword combinations. As early as 1984, Huddleston (1984: 259) pointed out that: "we have to accept that the distinction between the phrasal and compound noun construction is fuzzy."

The underlying meaning of adjectives is an important contributor to nominal syntagmatic units of different kinds: complex terminological units (CTUs) and collocations. While some adjectives constrain the meaning of the noun, constructing other specific lexical units, others simply reveal the descriptive aspects of terms. According to Zelinsky-Wibbelt (2012: 228), CTUs and collocations are "multi-word units, which integrate their constituents into semantically and formally fixed units to different degrees." A noted difficulty in this respect is to discover the degree to which the constituents are syntagmatically attracted in a domain (Kageura and Umino 1996). The greatest attraction between constituents (premodifier + head) results in lexicalized units; these are CTUs, which, as indicated by Zelinsky-Wibbelt (2012), present a tighter integration of their individual constituents than within collocations. CTUs are essential in terminology extraction as a high percentage of domain specific concepts are designated by nominal compounds (Nakagawa and Mori 2003).

Since both types of information are useful when describing terminology and structuring a specialized knowledge field, adjectives can be included in terminological dictionaries as part of two types of multi-word units: as constituents of nominal entries (CTUs) or as collocates of nouns (collocations) in subentries of these same nouns.

In terminographic practice in English in the domain of karstology, adjectives have a great presence. They appear primarily as participants in complex nominal terms, thus functioning as premodifiers of simple or compound nouns. Some adjectives have also been presented as entries by themselves. No subentries have been considered. For the entries presented in specialized glossaries, relevant co-text is missing and no pragmatic information is given.

This paper seeks mainly to study the role of attributive adjectives in syntagmatic units within the specialized language of karstology. Only attributive adjectives have been considered as it is assumed that this position promotes the termhood ${ }^{2}$ of the unit in English, although this is not always the case. The specific objectives of our study are:

- to describe the polymorphic behaviour of adjectives from different perspectives: morphological, semantic and syntactic;

- to see if this description might help to explain the degree to which the constituents are syntagmatically attracted in karstology, so as to result in CTUs or collocations;

- to reflect on the contribution of the study of adjectives to the conceptual structure of a knowledge field. 


\section{Methodology}

\subsection{Description of the specialized corpus}

This study is based on a 913.416 token monolingual specialized corpus (see Appendix 1), created according to the needs of translators, students and experts. Given the potential target audience, the study focuses on communicative settings of different degree of specialization: expert to expert and expert to semi-expert; thus, various genres have been chosen for the corpus. The corpus contains two subcorpora, a scientific subcorpus, which consists of $\mathrm{PhD}$ theses, research articles published in international journals, and conference proceedings which contain research articles, conference programs and welcome notes from specialized associations, and a didactic subcorpus, which is made up of student manuals and course books.

TABLE 1

Detailed description of the specialized corpus

\begin{tabular}{|c|c|c|c|c|c|c|}
\hline \multirow[b]{2}{*}{$\begin{array}{l}\text { Number of } \\
\text { texts }\end{array}$} & \multicolumn{3}{|c|}{ Scientific subcorpus } & \multicolumn{3}{|c|}{ Didactic subcorpus } \\
\hline & $\begin{array}{l}3 \mathrm{PhD} \\
\text { theses }\end{array}$ & $\begin{array}{l}16 \text { research } \\
\text { articles from } \\
\text { journals }\end{array}$ & $\begin{array}{l}4 \text { conference } \\
\text { proceedings }\end{array}$ & $\begin{array}{l}9 \text { student } \\
\text { manuals }\end{array}$ & $\begin{array}{l}4 \text { book } \\
\text { chapters }\end{array}$ & 4 books \\
\hline $\begin{array}{l}\text { Total number } \\
\text { of texts per } \\
\text { subcorpus }\end{array}$ & \multicolumn{3}{|c|}{23 texts } & \multicolumn{3}{|l|}{17 texts } \\
\hline $\begin{array}{l}\text { Total size of } \\
\text { each subcorpus }\end{array}$ & \multicolumn{3}{|c|}{499.442 tokens } & \multicolumn{3}{|c|}{413.974 tokens } \\
\hline
\end{tabular}

Both subcorpora contain original texts, not translations, published between 1972 and 2013. They deal with the field of karstology and to be selected they had to include at least one of the key words set in advance (e.g., name of landforms such as karst, doline, uvala, spring, and aquifer, or some typical process for the formation of landforms such as erosion and dissolution).

\subsection{Description of the specialized domain}

Karstology is an interdisciplinary discipline where geological, hydrogeological, pedological and geomorphological factors intervene in order to present karst phenomena from different points of view.

Karst phenomena encompass karst groundwater systems (hydrogeology) and karst landforms (geomorphology), both above and below the surface. The heterogeneous nature of karst led us to focus on the main parameters for its classification. We distinguished physical properties such as size, shape and distribution, as well as lithological properties like rock purity, grain size and texture. Different authors have confirmed that petrological, lithological and structural features greatly influence all aspects of karst genesis (Ford and Williams 2007).

Our corpus refers mainly to karst phenomena found within the specific limestone region known as the Dinaric Karst. It is considered the paramount karst of Europe and the type-site of many karst features (Williams 2011).

According to the principles of Process-Oriented Theory (Faber et al. 2006) and its macrocategories [AGENT $\rightarrow$ PROCESS $\rightarrow$ PACIENT/RESULT], a karst event 
could be described as activated by natural activators (AGENT), which cause PROCESSES on the soluble rocks (PACIENT) and result in the diversity of landforms. A prototypical event in the karst domain could be presented using a formula such as the following:

Natural AGENT: water activated by river erosion, tectonics, glaciation $\rightarrow$ causes a PROCESS: dissolution, sedimentation $\rightarrow$ operates on the: PACIENT: soluble rocks (carbonate and evaporate rocks) $\rightarrow$ RESULTS in: typical karst landscape (sinkholes, caves, springs, sinking streams....)

Karst events appear on different locations such as hydrological and geochemical karst subsystems. This causes diverse karst landforms; the variety of adjectives used for their description has led us to analyze their role in karst terminology.

\subsection{Term extraction}

In order to study the role of adjectives in complex term extraction, a list of the most frequent and topic-relevant nouns and adjectives was first extracted. By using the function Wordlist in WordSmith Tools 6.0 (Scott and Tribble 2006; Scott 2008), a hundred candidate terms were selected: fifty nouns and fifty adjectives. To aid in the selection process a general stop list and a specialized lemma list were used. Frequency was considered key for the selection of candidate terms in this study because it is believed that the higher the frequency, the more syntagmatic relations lexical units can have. For example, the noun karst with 9.114 occurrences in the corpus has produced 19 multiword combinations (e.g., tower karst, hydrothermal karst, dinaric karst, etc.) while exokarst with 23 occurrences has produced none. Needless to say, all candidates had to be confirmed by experts as relevant in the karst landscape.

TAble 2

Extraction of noun candidate terms

\begin{tabular}{|c|c|}
\hline $\begin{array}{l}\text { SIMPLE CANDIDATE TERMS } \\
\text { NOUNS }\end{array}$ & FREQUENCY \\
\hline 1. KARST & 9.114 \\
\hline 2. WATER & 5.653 \\
\hline 3. CAVE & 3.457 \\
\hline 4. FLOW & 2.734 \\
\hline 5. LIMESTONE & 1.677 \\
\hline 6. GROUNDWATER & 1.465 \\
\hline 7. $\mathrm{ROCK}$ & 1.263 \\
\hline 8. AQUIFER & 1.170 \\
\hline$\ldots$ & $\ldots$ \\
\hline 48. IAYER & 258 \\
\hline 49. FAULT & 255 \\
\hline 50. CORROSION & 252 \\
\hline
\end{tabular}


TABLE 3

Extraction of adjective candidate terms

\begin{tabular}{|c|c|}
\hline $\begin{array}{l}\text { SIMPLE CANDIDATE TERMS } \\
\text { ADJECTIVES }\end{array}$ & FREQUENCY \\
\hline 1. HYDRAULIC & 690 \\
\hline 2. GEOLOGICAL & 570 \\
\hline 3. KARSTIC/KARST & 438 \\
\hline 4. DINARIC & 420 \\
\hline 5. GLACIAL & 282 \\
\hline 6. HYDROLOGICAL & 266 \\
\hline 7. TECTONIC & 260 \\
\hline 8. PHREATIC & 248 \\
\hline \multicolumn{2}{|l|}{$\ldots$} \\
\hline 48. ENDOKARSTIC & 36 \\
\hline 49. DOLOMITIC & 34 \\
\hline 50. ENDOGENIC & 28 \\
\hline
\end{tabular}

The relevance of terms was finally confirmed by comparing them with entries in specialized glossaries. In this regard, we have followed the bidirectional approach between corpus data and dictionaries presented by Josselin-Leray (2005). The application of this kind of functionalist approach offers a better perspective on the term's discourse value, its semantic load and its complexity on the level of combinatory potential.

The glossaries chosen for this study are: A Lexicon of Cave and Karst Terminology with Special Reference to Environmental Karst Hydrology (2002), ${ }^{3}$ A Glossary of Hydrological Terms (2007), ${ }^{4}$ Glossary of Speleogenesis (online) ${ }^{5}$ and Glossary of Karstic Phenomena (2013). ${ }^{6}$ These glossaries have a terminographic approach as they include specialized vocabulary and not general words. They contain above all nominal term entries made up of one to three constituents. Some of them include a small number of adjectival entries, although verbs have not been covered. Considering that these glossaries have been created by experts in the field of karstology, it seemed logical to compare our candidate terms with the entries included in the glossaries. Candidate terms have been considered key terms if they appeared in at least one of these glossaries. This requirement helped us to find not only frequent terms in the domain but also those recognized by experts. A total of 49 candidate terms have matched entries in these terminological sources, and therefore are considered key terms in this study. 36 out of the resulting key terms are nouns while only 13 are adjectives. Although the number of adjectives is much lower than the number of nouns, their very presence proves that adjectives can also acquire independent terminological value within a field.

On the basis of previous studies (Kageura and Umino 1996; Nakagawa and Mori 2003), we assume that complex nominal terms tend to be made from existing simple terms. Therefore, we consider that the termhood of a complex nominal term is linked to the termhood of at least one constituent of the complex unit. In the second part of the term extraction process, all the resulting key terms were used to extract syntagmatic combinations with a minimum frequency of 3 occurrences in the corpus found in at least 2 different texts. For the selection process, the word sketch function ${ }^{7}$ 
provided by the tool Sketch Engine was used (Kilgarriff et al. 2004). This way we could observe and describe syntagmatic combinations with at least one key term:

- ADJ + NOUN (key term);

- ADJ (key term) + NOUN;

- ADJ (key term) + NOUN (key term).

The word sketches are presented to the user as a list of relations, with items in each list ordered by salience (Kilgarriff and Tugwell, 2001). The salience score combines Mutual Information and log frequency measures. It guaranties the selection of fine-grained patterns of significant multiword units, situating those of greatest relevance in the beginning of the list. Among the high-salience grammatical relations a word sketch can provide, we were interested in the grammatical relation modifier + noun. Table 4 shows the list of collocates for the word cave. It has been slightly abbreviated in order to show just the most relevant data but it hasn't been modified in any other way.

TABLE 4

Word sketch for cave

\begin{tabular}{|l|c|c|}
\hline modifier & num. & sal. \\
\hline unroofed & 33 & 9.44 \\
\hline large & 41 & 8.85 \\
\hline deep & 31 & 8.82 \\
\hline small & 27 & 8.42 \\
\hline horizontal & 16 & 8.26 \\
\hline maze & 12 & 7.92 \\
\hline long & 14 & 7.87 \\
\hline old & 13 & 7.86 \\
\hline single & 12 & 7.81 \\
\hline tropical & 12 & 7.75 \\
\hline sulfidic & 10 & 7.74 \\
\hline artificial & 9 & 7.5 \\
\hline active & 10 & 7.47 \\
\hline limestone & 28 & 7.41 \\
\hline vertical & 10 & 7.41 \\
\hline
\end{tabular}

The main difficulty when distinguishing syntagmatic relations has been differentiating the degree of unithood of the constituents within combinatory structures (Kageura and Umino 1996: 260). This study supports the importance of the polymorphic behaviour of adjectives in that they are context dependent (Sanfilippo et al. 1998), and it wishes to contribute to the explanation of the role of adjectives. Thus, the aim of this study is to analyze their polymorphic behaviour from a morphological, semantic and syntactic perspective and to reflect on how this behaviour affects the conceptual structure of the field. 


\subsection{Data analysis}

\subsubsection{Morphological point of view}

The adjectives participating in syntagmatic units in this study, which only takes into account the English language and a specialized language in particular, can be classified into different groups. There are mainly relational adjectives, adjectival nouns, deverbal adjectives and qualifying adjectives.

Relational adjectives derive from nouns, and their behaviour is closer to that of nouns than to that of adjectives (Bosque 1993; Fabregas 2007; Rainer 2013). According to Fabregas (2007: 7), relational adjectives are an instance of transposition, which is a lexeme whose grammatical label has been changed without altering the rest of its properties. They often take the morphological shape of an adjective by means of a suffix (for instance alluvial doline, depositional karst). The morphological aspect of relational adjectives is linked to semantico-syntactic aspects. Semantically, a relational adjective is equivalent to a noun modifying another (e.g., alluvial aquifer: an aquifer composed of alluvium). Relational adjectives, like nouns, are not gradable: they "do not exhibit degree information" (Fabregas 2007: 4) ( ${ }^{*}$ very alluvial, ${ }^{*}$ a little alluvial). Syntactically, relational adjectives can be subclassified into two subtypes: thematic relational adjectives and classifying relational adjectives (Bosque 1993). The thematic relational adjectives correspond to arguments of the theta grid of the head noun. In the example fluvial erosion, fluvial is the agent that intervenes in the process of erosion. This is proof of the noun-like behaviour of relational adjectives, because only nouns can be considered arguments. Other relational adjectives do not correspond to arguments in the theta grid but aim to classify the head noun within a domain or subdomain. Bosque (1993) calls this type of adjective classifying relational adjectives (calcareous rocks, carboniferous limestone).

The second type of adjectives constituting syntagmatic units in karstology is adjectival nouns, also called attributive nouns. These are nouns that premodify another noun, thus functioning as adjectives in English (underground water, water table, karst landform). It should be noted that the use of these adjectival nouns is frequent, even if an adjectivally inflected alternative exists (karst/karstic landscape, karst/karstic aquifer). Although both forms are used, our corpus shows that karst is more broadly used than karstic in the premodifier position. For example karst aquifer has got 700 occurrences while karstic aquifer only occurs 46 times; the same is true of karst/karstic landscape: karst landscape has 185 occurrences while karstic landscape only occurs 3 times. The options seem to be interchangeable with no semantic difference, although the adjectival noun is more commonly used.

The third important type of adjectives found in the syntagmatic units is the deverbal ones. Most of them are past participles, which, contrary to -ing-adjectives, express the result of an activity instead of its development (closed depression, confined aquifer, saturated zone, unsaturated zone). This is called the stative use of deverbal adjectives. They entail there having been a preceding event giving rise to the state named by the deverbal adjective (Koontz-Garboden 2011: 285).

Finally, qualifying adjectives have also been found in our syntagmatic units. They describe qualities of nouns (deep doline, warm water, rounded doline). These qualities can vary in intensity as opposed to relational adjectives (very deep, extremely deep). 
From this analysis, we conclude that the morphological pattern of adjectives can help terminographers distinguish different types of syntagmatic units:

- Relational adjectives, especially the classifying ones, have a specialized meaning within the domain (for instance phreatic, allogenic). Some of them have been considered key terms in this study due to their frequency and the glossary check. They tend to promote the formation of complex nominal terms making concepts more specific, and thus, helping to classify the domain (phreatic cave, allogenic river).

- Most qualifying adjectives belong to the general language and when combined with key noun terms usually promote collocations (deep doline, small doline). There are some exceptions where qualifying adjectives acquire a terminological sense when combined with key noun terms. Only in these cases do qualifying adjectives take on the role of constituents of complex nominal terms. For instance, active in the general language means "busy/involved in a particular activity" (Cambridge Dictionary Online) while active cave means "a cave containing a running stream" (Glossary of Speleogenesis Online). What's more, the adjective active covers a different meaning depending on which noun it modifies: active water means "water with corrosive properties" (Glossary of Speleogenesis Online). The difference between qualifying adjectives and relational adjectives derived from nouns is that the first indicate a quality or a property while the second determine the relation between two concepts. This information is often used in definitions.

- Adjectival nouns usually promote complex nominal terms as the addition of a premodifying noun can transform a general word into a complex unit with specialized meaning (water table).

- From the data, it can also be inferred that deverbal adjectives tend to promote lexicalized units with greater frequency. Sometimes, deverbal adjectives come from the general language but acquire terminological status when combined with a key noun term ( closed depression). At other times, deverbal adjectives have terminological status by themselves and therefore when they combine with a head noun, they usually construct a complex nominal term (confined aquifer). This can happen even if the head is a general noun (saturated zone, unsaturated zone). This means that adjectives are not only participants in complex nominal terms; they can also actively promote the termhood of the unit.

\subsubsection{Semantic point of view}

Semantically, adjectives "specify further properties of the class from which referents are drawn" (Huddleston 1984: 256). Relying on the distributional transformational model proposed by Harris $(1968,1970)$, the Lexicon-Grammar model (Gross 1995; Le Pesant and Mathieu-Colas 1998) introduced the notion "class of object" in order to illustrate the dependence relation between a predicate and its arguments. Due to the restricted relations between the constituents of syntagmatic units, this kind of semantic class can offer a wider perspective of the rules governing the lexical patterns. According to the properties or attributes premodifiers assign, it is possible to group them in various knowledge sets, stating the characteristic upon which each set is based. Table 5 shows the semantic groups of adjectives proposed on the basis of the relation between nouns and adjectives selected in this study: 
TABLE 5

Knowledge sets of adjectives

\begin{tabular}{|c|c|}
\hline Knowledge sets & $\begin{array}{l}\text { Examples of } \\
\text { syntagmatic structures }\end{array}$ \\
\hline 1) GENESIS & $\begin{array}{l}\text { allogenic river } \\
\text { collapse doline } \\
\text { solutional doline }\end{array}$ \\
\hline 2) POROSITY & $\begin{array}{l}\text { double porosity } \\
\text { granular aquifer } \\
\text { fractured limestone }\end{array}$ \\
\hline 3) CHEMICAL COMPOUND & $\begin{array}{l}\text { calcareous deposit } \\
\text { carbonic acid } \\
\text { sulfuric acid }\end{array}$ \\
\hline $\begin{array}{l}\text { 4) CONTENT/CONSTITUTIVE } \\
\text { MATERIAL }\end{array}$ & $\begin{array}{l}\text { alluvial aquifer } \\
\text { clastic rock } \\
\text { cretaceous sediment }\end{array}$ \\
\hline 5) GEOLOGICAL STRUCTURE & $\begin{array}{l}\text { confined aquifer } \\
\text { unconfined aquifer } \\
\text { artesian aquifer }\end{array}$ \\
\hline 6) POSITION/LOCATION & $\begin{array}{l}\text { phreatic cave } \\
\text { underground stream } \\
\text { superficial deposit } \\
\text { subterranean river }\end{array}$ \\
\hline 7) SHAPE & $\begin{array}{l}\text { bedded limestone } \\
\text { conical karst } \\
\text { closed depression }\end{array}$ \\
\hline 8) MANNER & $\begin{array}{l}\text { turbulent flow } \\
\text { steady flow } \\
\text { intense dissolution }\end{array}$ \\
\hline 9) SIZE & $\begin{array}{l}\text { enlarged conduit } \\
\text { extensive cave }\end{array}$ \\
\hline 10) STATE & $\begin{array}{l}\text { dry cave } \\
\text { flooded polje }\end{array}$ \\
\hline 11) TEMPERATURE & $\begin{array}{l}\text { cold water } \\
\text { warm water } \\
\text { thermal spring }\end{array}$ \\
\hline 12) TIME & $\begin{array}{l}\text { perennial spring } \\
\text { permanent lake } \\
\text { seasonal lake }\end{array}$ \\
\hline
\end{tabular}

This kind of paradigmatic analysis allows us to see that it is the semantic nature of the predicate which imposes selection restrictions on the arguments.

In addition, key noun terms have also been assigned to different knowledge sets as they are often starting points for the formation of syntagmatic units (see Table 6).

The proposed semantic classification contributes to the organization of the conceptual structure and the definition of concepts. For example, nominal predicates denoting landforms select adjectives predominantly from the set of shape and constitutive material. On the other hand, adjectival predicates such as karstic combine with nouns that belong to the following semantic sets: landforms, hydrology and rocks.

For terminographic purposes, the meaning of adjectives is said to be an important motivating force for recognizing syntagmatic units as complex nominal terms or collocations (Zelinsky-Wibbelt 2012: 226). Although all adjectives may be interesting because they reveal different points of view of the key terms, only the most significant 
TABLE 6

Knowledge sets of key noun terms

\begin{tabular}{|l|l|}
\hline Knowledge sets & Noun key terms \\
\hline 1) LANDFORMS & cave \\
& polje \\
& doline \\
& uvala \\
& sinkhole \\
& cavity \\
& passage \\
& formation \\
& depression \\
\hline 2) ROCKS & karst \\
& limestone \\
& rock \\
& sediment \\
& calcite \\
& fracture \\
& fault \\
& layer \\
\hline 3) HYDROLOGY & flow \\
& aquifer \\
& spring \\
& groundwater \\
& river \\
& basin \\
& stream \\
& discharge \\
& conduit \\
& lake \\
& recharge \\
& joint \\
\hline & porosity \\
& permeability \\
\hline & dissolution \\
& precipitation \\
& infiltration \\
& karstification \\
corrosion \\
\hline
\end{tabular}

ones allow the creation of complex nominal terms. As seen in table 5, the first five knowledge sets of adjectives (genesis, porosity, chemical compound, constitutive material and geological structure) seem to trigger new complex nominal terms; the addition of the adjective to the following noun favours a new concept (for example doline $>$ collapse doline, subsidence doline). On the other hand, the last sets referring to manner, size, state, temperature and time trigger collocations (small doline, dry cave, temporary lake), whose overall meaning can be understood by the sum of the meanings of the constituents. Collocates merely describe objects, which are mostly landforms, without creating new concepts; but they enrich the understanding of concepts and promote the right usage of the corresponding terms in context.

The knowledge sets in the middle part of the list, position/location and shape do not seem to be totally clear indicators of the type of syntagmatic units they participate in. As can be observed in table 5, the knowledge set of adjectives position/location includes complex nominal terms such as phreatic cave and collocations such as superficial deposit and the knowledge set shape includes complex nominal terms such as 
closed depression or conical karst and collocations such as deep aquifer or shallow depression. The distinction between complex terms and collocations required further analysis; units considered complex nominal terms could not be understood by the sum of the meaning of their constituents; furthermore, they were found as defined entries in the cited glossaries. Examples of use from our corpus also helped us distinguish between the two types of units.

\subsubsection{Syntactic point of view}

Syntactically, a multiword unit made up of an adjective and a noun can result in a lexical unit or in a lexico-syntactic unit depending on the relation between the constituents. Only lexicalized units in which the order of the constituents is fixed and thus function as single units repeatedly are considered complex nominal terms (e.g., granular aquifer, karst aquifer).

On the contrary a lexico-syntactic unit, that is a collocation, has been defined as a "habitual word combination, although not necessarily completely fixed. [...] Collocations do not represent one part of speech. Their components are still seen as separate units. But collocations can, over time, become completely lexicalized" (Roberts 1998: 65). This definition helps clarify the distinguishing characteristics of a collocation in contrast to those of a complex nominal term. As the author points out, although a term (base of the collocation) co-occurs with a collocate habitually, they are still independent of each other. Therefore, it can be inferred that the constituents of a collocation maintain a syntactic relationship in which the function of the collocate may change from attributive to predicative position. The following examples may clarify the relatively frequent co-occurrence of the collocate deep with the term aquifer and its low level of lexicalization:

deep aquifer; deep parts of karst aquifer; deep, partially confined, fractured rock aquifer; aquifer is deep underground; mile-deep aquifer.

Apart from observing KWIC concordances and word sketches, and checking frequency in the specialized corpus, searching for multiword units in entries of specialized glossaries has been tremendously useful when confirming the status of a syntagmatic unit as a complex nominal term.

TABLE 7

Checking resulting syntagmatic units in glossaries

\begin{tabular}{|l|c|c|c|c|}
\hline Syntagmatic units & $\begin{array}{l}\text { A Glossary of } \\
\text { Hydrogeological } \\
\text { Terms }\end{array}$ & $\begin{array}{l}\text { A Lexicon of } \\
\text { Cave and Karst } \\
\text { Terminology }\end{array}$ & $\begin{array}{l}\text { Glossary } \\
\text { Speleogenesis }\end{array}$ & $\begin{array}{l}\text { Glossary of Karstic } \\
\text { Phenomena }\end{array}$ \\
\hline Collapse doline & 0 & $\sqrt{ }$ & $\sqrt{ }$ \\
Subsidence doline & 0 & 0 & $\sqrt{ }$ & 0 \\
Deep doline & 0 & 0 & 0 & 0 \\
\hline
\end{tabular}

\subsubsection{Ontological point of view}

The addition of adjectives to generic concepts can give rise to hierarchical relations between complex nominal terms and between complex nominal terms and simple nominal terms. On the one hand, they can show generic-specific relations, which is 
the most common relation type according to terminological studies (Kageura 1997: 128). For example, the hyperonym aquifer can be classified on the basis of its permeability into several hyponyms: granular aquifer, fractured aquifer and double porosity aquifer. Hyponomy can appear if there is compositional meaning (Zelinsky-Wibbelt 2012: 228).

On the other hand, adjectives can also contribute to a classificatory organization in that they integrate concepts into a broader concept, thus establishing whole/part relations. For instance, groundwater system (zone of recharge where surface water enters subsurface) can be divided into several parts: unsaturated or vadose zone, water table and saturated or phreatic zone.

From an ontological perspective, the phenomenon of multidimensionality introduced by Bowker (1992) and developed by Bowker and Meyer (1993) has been considered in detail as it helps to represent the dynamism of a specialized field such as karstology. According to Bowker and Meyer (1993: 123), multidimensionality "is a phenomenon of classification that arises when a concept type can be subclassified in more than one way [...], depending on the conceptual characteristic that is used as a basis for the subclassification." In this regard, significant adjectives can guide terminologists to classify a concept in several ways. For example, the hyperonym aquifer can be classified not only according to permeability, as stated earlier, into different hyponyms: granular aquifer, fractured aquifer and double porosity aquifer, but also according to evolution: confined aquifer and unconfined aquifer.

Multidimensionality is also present in karstology when several viewpoints are highlighted by one and the same adjective occurring with different concepts. This means that the combination of an adjective with different nouns can lead to classifying this adjective into different knowledge sets. For instance, fluvial can belong to the knowledge set origin/genesis in fluvial erosion or to location in fluvial organism. Moreover, the meaning of the adjective alluvial in complex nominal terms can be interpreted by paraphrasing it in two ways too:

- <material $>$ composed of alluvium (water-transported material);

- <origin> deposited by a stream or running water.

The recognition of all dimensions of a concept through real data allows terminologists to produce precise term records and a broader and deeper view of the field.

\subsubsection{Term records}

On the basis of the information extracted from the corpus, we have developed some term record samples. The aim was to show how the methodology and the data analysis could be applied to glossary-making.

Each record sample includes several categories: lexical category, definition, ${ }^{8}$ context from the cited corpus, resulting complex nominal terms if any, resulting collocations if any, knowledge set(s) to which simple or complex units belong and cross reference if needed. 
TABLE 8

Term record: alluvial

\begin{tabular}{|l|l|}
\hline Alluvial & \\
\hline Lexical category & Adj. \\
\hline Definition & $\begin{array}{l}\text { Which is composed of different kind of sediments deposited by running } \\
\text { streams. }\end{array}$ \\
\hline Context & $\begin{array}{l}\text { Alluvial aquifers are also likely to be vulnerable, unless they contain a high } \\
\text { proportion of clay-rich material to reduce their permeability, are overlain by a } \\
\text { protective confining layer of clays and/or the water table is relatively deep. }\end{array}$ \\
\hline CTUs & $\begin{array}{l}\text { Alluvial doline; alluvial notch; alluvial plain; alluvial aquifer; alluvial deposit; } \\
\text { alluvial material; alluvial sediment; alluvial fan; alluvial corrosion. }\end{array}$ \\
\hline Knowledge set(s) & Origin; constitutive material \\
\hline Cross-reference & Alluvium \\
\hline
\end{tabular}

TABLE 9

Term record: aquifer

\begin{tabular}{|l|l|}
\hline Aquifer & \\
\hline Lexical category & Noun \\
\hline Definition & Body of rock that can store and transmit significant quantities of water. \\
\hline Context & $\begin{array}{l}\text { We trace the caves in the wider area of the traffic route, determine their type, } \\
\text { position, and role in the aquifer, their shape, rock relief, the alluvia and } \\
\text { flowstone found in them, and present them on suitable maps. }\end{array}$ \\
\hline Collocations & Deep aquifer, coastal aquifer, porous aquifer, transboundary aquifer. \\
\hline CTUs & $\begin{array}{l}\text { Karst aquifer; karstic aquifer; carbonate aquifer; limestone aquifer; } \\
\text { unconfined aquifer; fractured aquifer; artesian aquifer; intergranular aquifer; } \\
\text { granular aquifer; alluvial aquifer; dolostone aquifer; rock aquifer; confined } \\
\text { aquifer; karstified aquifer; shallow aquifer; clastic aquifer. }\end{array}$ \\
\hline Knowledge set(s) & Landform \\
\hline
\end{tabular}

TABLE 10

Term record: alluvial aquifer

\begin{tabular}{|l|l|}
\hline Alluvial aquifer & \\
\hline Lexical category & Noun \\
\hline Definition & $\begin{array}{l}\text { Body of rock which comprises unconsolidated material (e.g., clay, sand, etc.) } \\
\text { deposited by running water. }\end{array}$ \\
\hline Context & $\begin{array}{l}\text { In areas where the aquifer is confined, recharge enters the alluvial aquifer by } \\
\text { downward leakage through the confining unit. }\end{array}$ \\
\hline Knowledge set(s) & Content/constitutive material \\
\hline
\end{tabular}

\section{Conclusion: implications for terminography}

In this paper, we have tried to contribute to the description of adjectives in terminology and highlight their great importance in terminographic applications. The polymorphic behaviour of adjectives from a morphological, semantic, syntactic and ontological point of view has shown that adjectives are a flexible category that can achieve terminological status in their own right as attested in the terminological record alluvial, promote the formation of further complex nominal terms as shown in the terminological record alluvial aquifer or simply describe object concepts within a field. We aimed at applying this methodology to the field of karstology to help 
terminographers, terminologists and translators to develop skills when dealing with adjectives in this particular field in English, above all when the adjectives become constituents of syntagmatic units and there is a need to differentiate CTUs (entries) from collocations (subentries of a specialized glossary).

According to the data analysis, several conclusions have been drawn. Hopefully they will shed some light on the behaviour of adjectives and on the different roles they play in syntagmatic units in the domain and language studied.

From the syntactic analysis, we concluded that the syntactic relation between constituents of a multi-word unit could help terminographers distinguish different types of syntagmatic units. From the data, it can be noted that the greater the integration of the constituents of a multi-word unit is, the more likely the unit is to acquire CTU status. And, in contrast, the looser the relation between adjective and noun within the multiword unit, the more likely it is that this combination is a collocation. The morphological and semantic analyses support the syntactic one. Relational adjectives and deverbal adjectives tend to have a greater integration with nouns within the field of karstology. The non-gradability of relational adjectives and the obligatory attributive position of relational adjectives and deverbal adjectives do not allow them to occupy other positions (for instance a predicative one) within the nominal phrase. Therefore, the fixed positions of the constituents promote the unithood of the complex nominal terms. In contrast, the qualifying adjectives are gradable and they generally have a flexible position. These characteristics point to a probably lower degree of integration between qualifying adjectives and base nouns. Besides, the meaning of adjectives also guides us to similar conclusions. Adjectives with specialized meaning in the field referring to topics such as genesis or geological structure usually have a tighter relation with nouns. Coincidentally, these adjectives are usually relational or deverbal ones. On the contrary, adjectives from the general language, which are used in karstology for descriptive purposes, have a looser relation with nouns. Thus, the combinatory structures of qualifying adjectives and nouns usually result in collocations.

The morphological, semantic and syntactic analyses of adjectives within syntagmatic structures have, from our point of view, implications for the organization of the conceptual structure of a specialized field such as karstology. In particular, the semantic analysis has been helpful for this purpose. The identification of knowledge sets of modifiers that clearly trigger complex nominal terms have proved to be relevant to set generic-specific and whole/part relations. Besides, the base expansions (collocates) make it possible to group objects that share a set of properties. Furthermore, adjectives have been shown to be essential for pinpointing the multidimensionality of concepts as the latter can be classified in different ways according to the semantic nature of its modifiers.

The analyses also provide information on the use of terms that can be included in term records to make them more precise and complete. Future work should include a contrastive study of salient attributes within multiword units in different languages in the same domain and in different domains. 


\section{NOTES}

1. According to Kageura and Umino (1996: 260), unithood "refers to the degree of strength or stability of syntagmatic combinations."

2. Termhood "refers to the degree that a linguistic unit is related to (or more straightforwardly, represents) domain-specific concepts" (Kageura and Umino 1996: 260).

3. A Lexicon of Cave and Karst Terminology with Special Reference to Environmental Karst Hydrology (2002): Supercedes EPA/600/R-99/006, 1/'99. Washington: National Centre for Environmental Assessment.

4. ShARP, John (2007): A Glossary of Hydrological Terms. Austin: University of Texas.

5. Glossary of Speleogenesis. International Portal for Researchers in the field of Karst and Cave with Speleogenesis and Evolution of Karst Aquifer at its core. Visited 1 April 2014, <http://www.speleogenesis.info/directory/glossary/>

6. VRbanAC, Boris (2013): Glossary of Karstic Phenomena. Nafta. 64(1): 64-76.

7. Word sketches "are one-page automatic, corpus-based summaries of a word's grammatical and collocational behaviour" (Kilgarriff, Rychly et al. 2004).

8. Adjective's definitions were created using a paraphrase model introduced by Carrière (2008).

\section{REFERENCES}

\section{Glossaries}

Alonso, Aracelli and Torner, Sergi (2010): Adjectives and Collocations in Specialized texts: Lexicographical Implications. In: Anne Dyкstra and Tanneke Schoonheim, eds. Proceedings of the XIV Euralex International Congress (Euralex, Leeuwarden, 6-10 July 2010). Ljouwert: Fryske Akademy, 872-881.

Bosque, Ignacio (1993): Sobre las diferencias entre los adjetivos relacionales y los calificativos. Revista Argentina de Lingüística. 10:10-48.

Boulllon, Pierrette (1997): Polymorphie et sémantique lexicale: le cas des adjectifs. Doctoral dissertation, unpublished. Paris: Université Paris VII.

Bouillon, Pierrette and Viegas, Evelyne (1999): The Description of Adjectives for Natural Language Processing: Theoretical and Applied Perspectives. In: TALN'99 workshop on Description des adjectifs pour les traitements Informatiques, Cargèse: Institut d'études scientifiques de Cargèse.

Bow KER, Lynne (1992): Guidelines for Handling Multidimensionality in a Terminological Knowledge Base. M.A. Thesis, unpublished. Ottawa: University of Ottawa.

Bowker, Lynne and Meyer, Ingrid (1993): Beyond "Textbook" concept systems: Handling multidimensionality in a new generation of term banks. In: Klaus-Dirk Schmitz, ed. TKE'93 Terminology and Knowledge Engineering. Frankfurt: Indeks Verlag, 123-137.

CARrIÈre, Isabelle (2008): MédiTerm: pour une désambiguisation des adjectifs médicaux. In: Matthieu Constant, Anne Dister, Louisette Emirkanian, Sophie Piron, éd. Description linguistique pour le traitement automatique du français. Louvain-la-Neuve: Presses Universitaires de Louvain.

Faber, Pamela, Montero, Silvia, Castro, María Rosa, et al. (2006): Process Oriented Terminology Management in the Domain of Coastal Engineering. Terminology. 12(2):189-213.

Fabregas, Antonio (2007): The Internal Syntactic Structure of Relational Adjectives. Probus. 19(1):1-36.

Fellbaum, Christiane, Gross Derek and Miller Katherine (1993): Adjectives in WordNet. In: George Miller et al. Five papers on WordNet. CSL Report. Princeton: Princeton University, 26-39.

Ford, Derek and Williams, Paul (2007): Karst Hydrogeology and Geomorphology. Chichester: Wiley.

Gross, Gaston (1995): Une sémantique nouvelle pour la traduction automatique: les classes d'objets. La tribune des industries de la langue et de l'information électronique, vol. 17-18-19. Paris: OFIL, 16-19.

HARris, Zellig (1968): Mathematical Structures of Language. New York: John Wiley and Son. 
Harris, Zellig (1970): Papers in Structural and Transformational Linguistics. Dordrecht: D. Reidel.

Huddleston, Rodney (1984): Introduction to the Grammar of English. Cambridge: Cambridge University Press.

Josselin-Leray, Amélie (2005): Place et rôle des terminologies dans les dictionnaires unilingues et bilingues. Étude d'un domaine de spécialité: volcanologie. Doctoral dissertation, unpublished. Lyon: Université Lyon II.

Kageura, Kyo and Umino, Bin (1996): Methods of Automatic Term Recognition: a Review. In: Terminology. 3(2):259-289.

Kageura, Kyo (1997): Multifaceted/Multidimensional Concept Systems. In: Sue Ellen Wright and Gerhardt Budin, eds. Handbook of Terminology Management, vol. 1. Amsterdam/ Philadelphia: John Benjamins, 118-132.

Kilgarriff, Adam and Tugwell, David (2001): Word sketch: extraction and display of significant collocations for lexicography. In: Proceedings of the Workshop on Collocations, ACL, 32-38.

Kilgarriff, Adam, Rychlý, Pavel, Smrž, Pavel and Tugwell, David (2004): The Sketch Engine. In: Geoffrey Williams and Sandra Vessier, eds. Proceedings of the $11^{\text {th }}$ EURALEX International Congress. Lorient: Université de Bretagne. 105-116.

Koontz-Garboden, Andrew (2011): The Lexical Semantics of Derived Statives. Linguistics and Philosophy. 33(4):285-324.

L’Homme, Marie-Claude (2004): Adjectifs Dérivés Sémantiques (ADS) dans la Structuration des Terminologies. In: Actes de terminologie, ontologie et représentation des connaissances. 22-23 janvier 2004. Lyon: Université Jean-Moulin Lyon-3,

Lorente, Mercé (2001): Terminología y fraseología especializada: del léxico a la sintáxis. In: Manuel Pérez and Gloria Guerrero, eds. Panorama actual de la Terminología. Málaga: Comares, 159-180.

Lyons, John (1977): Semantics. Cambridge: Cambridge University Press.

Le Pesant, Denis and Mathieu-Colas, Michel (1998): Introduction aux classes d'objets. Langages. 131:6-33.

MARquez, Eduardo (1998): Classification des adjectifs: étude exploratoire sur l'organisation sémantique-pragmatique des adjectifs. Langages. 132:87-107.

Mendes, Sara (2006): Adjectives in WordNet. In: Proceedings of the 3rd Global WordNet Association Conference. Jeju Island, Korea, 225-230.

Miller, George A., Beckwith, Richard, Fellbaum, Christiane, et al. (1993): Five Papers on WordNet. CSL Report 43, Princeton: Princeton University.

Miller, Katherine J. (1998): Modifiers in WordNet. In: Christiane Fellbaum, ed. WordNet: an Electronic Lexical Database. Cambridge: The MIT Press, 47-68.

Nakagawa, Hirosi and Mori, Tatsunori (2003): Automatic Term Recognition Based on Statistics of Compound Nouns. Terminology. 9(2):201-219.

Normand, Sylvie and Bourigault Didier (2001): Analysing Adjectives Used in a Histopathology Corpus with NLP Tools. Terminology 7(2): 155-165.

Rainer, Franz (2013): Can Relational Adjectives really Express any Relation? An Onomasiological Perspective. International Journal of Social Sciences and Education 10(1):12-41.

Roberts, Roda (1998): Phraseology and translation. In: Purificación, Fernández and José María BRAVo, eds. La traducción: orientaciones lingüísticas y culturales. Valladolid: Universidad de Valladolid, 61-77.

Sanfilippo, Antonio, Calzolari, Nicoletta, Ananiadou, Sophia, et al. (1998): EAGLES Preliminary Recommendations on Semantic Encoding. The EAGLES Lexicon Interest Group.

Sсотт, Mike (2008): Developing WordSmith. International Journal of English Studies, 8(1):153172.

Scott, Mike and Tribble, Christopher (2006): Textual Patterns: Key Words and Corpus Analysis in Language Education. Amsterdam: Benjamins. 
Venant, Fabienne (2007): Utiliser des classes de sélection distributionnelle pour désambiguïser les adjectifs. Actes de la $14^{e}$ Conférence de Traitement Automatique des Langues Naturelles - TALN'07, Juin 2007, Toulouse, France. 187-196.

Williams, Paul (2011): Karst in UNESCO World Heritage Sites. In: Philip E. Van Beynen, ed. Karst Management. Springer, 459-480.

Zelinsky-Wibbelt, Cornelia (2012): Identifying Term Candidates through Adjective-Noun Construction in English. Terminology. 18(2):226-242.

\section{APPENDICES}

\section{Appendix 1: Corpus}

\section{Didactic subcorpus}

Andreychouk Viacheslav, Dublyansky Yuriy, Ezhov Yuriy, et al. (2009): Karst in the Earth's Crust: its Distribution and Principal Types. Sosnowiec (Poland) - Symferopol (Ukraine): University of Silesia - Ukrainian Institute of Speleology and Karstology.

BlaIR, Robert (1986): Karst Landforms and Lakes. In: Nicholas SHORT and Robert Blair, eds. Geomorphology from Space. United States: National Aeronautics and Space Administration.

Department of Geography and Environmental Sciences (2012): GEOG 1202, Introduction to Physical Geography. University of Colorado Denver. <http://catalog.ucdenver.edu/ preview_course_nopop.php?catoid=6\&coid=39128>.

Environmental Science Institute (2015): What is Karst? University of Texas, Austin.: <http:// www.esi.utexas.edu/outreach/k-12-teacher-and-informal-educator-resources/caves-awindow-into-the-edwards-aquifer/what-is-karst/>.

Goldscheider, Nico and Drew, David (2007): Methods in Karst Hydrogeology. London: Taylor and Francis.

Hopkins, Stan (2013): Geography 1113, Karst Landscapes (lecture 13). University of Georgia. $<$ http://www.studyblue.com/notes/note/n/karst-landscapes-lecture-13/deck/5790441>

Krygier, John B. (2005): Geography 111, Introduction to Physical Geography and Environmental Studies. Delaware: Ohio Wesleyan University. <http://go.owu.edu/ jbkrygie/krygier_html/ geog_111/geog_111_lo/geog_111_lo13.html $>$.

Lemke, Karen A. (2014): Karst Processes \& Landforms. University of Wisconsin. <http://www4. uwsp.edu/geo/faculty/lemke/geomorphology/lectures/07_karst.html>.

Mineve, Andrej, Prelovsek, Mitja and Zupan, Nadja (2010): Introduction to the Dinaric Karst. Postojna: Institut za raziskovanje krasa ZRC SAZU and Karst Research Institute at ZRC SAZU.

Rosenberg, Matt (2015): Karst Topography and Sinkholes. <http://www.about.com>.

Stokes, Tim, Griffiths, Paul and Ramsey, Carol (2010): Karst Geomorphology, Hydrology and Management. In: Robin Pike, Todd Redding, Dan Moore et al., eds. Compendium of Forest Hydrology and Geomorphology in British Columbia. Land Management Handbook. $<$ http://www.for.gov.bc.ca/hfd/pubs/docs/lmh/Lmh66.htm>.

Sweeting, Marjorie (1972): Landforms. London and Basingstoke: Macmillan Press Ltd. Missouri Caves, Karst, and Springs. The Missouri Speleological Survey. <http://www.mospeleo.org/ ozark_caving/springs/sprkarst.htm >.

TAYlor, Charles and Greene, Earl (2008): Hydrogeologic Characterization and Methods Used in the Investigation of Karst Hydrology. In: Donald Rosenberry and James W. LABAugh, eds. Field Techniques for Estimating Water Fluxes between Surface Water and Ground Water. Reston: U.S. Geological Survey.

TAYLOR, Stephen (2015): Introduction, ES322 Geomorphology and Aerial Photo Interpretation. Western Oregon University. <http://www.wou.edu/las/physci/taylor/g322/intro.pdf >.

Tucker, Maurice, Wright, Paul and Dickson, Tony (1990): Preface. In: Maurice Tucker, ed. Carbonate Sedimentology. London: Blackwell Scientific Publications. 
Yu, Zhongbo (2015): GEO 101, Physical Geography. Weathering, Karst, and Mass Movement. Department of Geoscience. University of Nevada, Las Vegas. <http://hydro.nevada.edu/ courses/geog101/notes/Chpt13.pdf>.

\section{Scientific subcorpus}

BonACCI, Ognjen et al. (2006): Karst flash floods: an example from the Dinaric karst (Croatia). Natural Hazards Earth System Sciences. 6:195-203.

BonaccI, Ognjen (2010): Sustainability of the Karst Environment. Dinaric Karst and Other Karst Regions. Proceedings of international interdisciplinary Scientific Conference. Plitvice, 23-26 September 2009. Paris: Unesco.

Bosak, Pavel (2002): Karst processes from the beginning to the end: How can they be dated? In: Franci GabrovseK, ed. Evolution of Karst: From Prekarst to Cessation. Postojna-Ljubljana, Zalozba ZRC, 155-190.

CALIC, Jelena (2009): Uvala - contribution to the study of karst depressions (with selected examples from dinarides and carpatho-balkanides). Doctoral dissertation, unpublished. Nova Gorica: University of Nova Gorica.

CALIC, Jelena (2011): Karstic uvala revisited: Toward a redefinition of the term. Geomorphology. 134(1-2):32-42.

Eberhard, Rolan and Sharples, Chris (2013): Appropriate terminology for karst-like phenomena: the problem with 'pseudokarst.' International Journal of Speleology. 42(2):109-113.

KranjC, Andrej (2006): Some large dolines in the Dinaric karst. Speleogenesis and Evolution of Karst Aquifers. 4(1).

MÁdL-Szonyi, Judit, Eross, Anita, Mindszenty, Andrea and Tóth, Adám, eds. (2013): International Symposium on Hierarchical Flow Systems in Karst Regions. 4-7 September 2013. Budapest.

Martin, Jonathan B. and White William B., eds. (2007): Frontiers of Karst Research. Proceedings, 3-5 May 2007. San Antonio, Texas,

Panisset Travassos, Luiz Eduardo (2011): The Cultural Importance of Karst and Caves. Doctoral dissertation, unpublished. Nova Gorica: University of Nova Gorica.

PARISE, Mario (2011): Surface and subsurface karst geomorphology in the Murge (Apulia, Southern Italy). Acta Carsologica. 40(1):79-93.

Perne, Matija (2012): Modelling speleogenesis in transition from pressurised to free surface flow. Doctoral dissertation, unpublished. Nova Gorica: University of Nova Gorica.

Zupan Hajna, Nadja (2008): Karst in Slovenia. Doctoral dissertation, unpublished. Available at: <http://www.theslovenian.com/articles/2008/hajna.pdf $>$.

Wong, Tim, Hamilton-Smith, Elery, Chape, Stuart, et al. (2001): Proceedings of the Asia-Pacific Forum on Karst Ecosystems and World Heritage. Gunung Mulu National Park World Heritage Area Sarawak. Malaysia, 26-30 May 2001.

Appendix 2: Multi-word combinations

\begin{tabular}{|l|l|}
\hline SIMPLE KEY TERMS & $\begin{array}{l}\text { MULTI-WORD COMBINATIONS AND THEIR OCCURRENCE } \\
\text { IN THE CITED CORPUS }\end{array}$ \\
\hline 1. KARST & $\begin{array}{l}\text { Tower karst (65), hydrothermal karst (50), dinaric karst (41), tropical karst } \\
\text { (36), contact karst (25), shallow karst (20), bare karst (18), hypogene karst } \\
\text { (17), cockpit karst (17), deep karst (21), relict karst (13), classical karst (13), } \\
\text { alpine karst (13), mountainous karst (10), cone karst (10), polygonal karst } \\
\text { (9), interstratal karst (8), lowland karst (8), silicate karst (8) }\end{array}$ \\
\hline 2. CAVE & $\begin{array}{l}\text { Unroofed cave (33), large cave (41), deep cave (31), small cave (27), } \\
\text { horizontal cave (16), maze cave (12), long cave (13), old cave (13), single } \\
\text { cave (12), tropical cave (12), sulfidic cave (10), accessible cave (10), active } \\
\text { cave (10), vertical cave (10), artificial cave (9), dry cave (8), underground } \\
\text { cave (7), shallow cave (6), big cave (6), major cave (6), water-table cave (4), } \\
\text { extensive cave (4) }\end{array}$ \\
\hline
\end{tabular}




\begin{tabular}{|c|c|}
\hline 3. FLOW & $\begin{array}{l}\text { Groundwater flow (174), turbulent flow (36), regional flow (28), diffuse } \\
\text { flow (20), fluid flow (20), overland flow (17), laminar flow (15), water flow } \\
\text { (98), base flow (15), subsurface flow (11), rapid flow (10), surface flow (27), } \\
\text { stream flow (16), conduit flow (20), free flow (8), pipe flow (8), } \\
\text { intermediate flow (7), epikarst flow (7), phreatic flow (8), unsaturated } \\
\text { flow (7), debris flow (7) }\end{array}$ \\
\hline 4. LIMESTONE & $\begin{array}{l}\text { Cretaceous limestone (37), Jurassic limestone (28), carboniferous } \\
\text { limestone (25), massive limestone (19), sparry limestone (16), pure } \\
\text { limestone (12), reef limestone (13), Eocene limestone (12), dolomitic } \\
\text { limestone (10), karstified limestone (10), compact limestone (9), soft } \\
\text { limestone (8), porous limestone (8), Permian limestone (6), Devonian } \\
\text { limestone (6), Triassic limestone (6), bare limestone (5), thin-bedded } \\
\text { limestone (4) }\end{array}$ \\
\hline 5. GROUNDWATER & $\begin{array}{l}\text { Karst groundwater (46), transboundary groundwater (10), aquifer } \\
\text { groundwater (6), old groundwater (5), valley groundwater (5), shallow } \\
\text { groundwater (4) }\end{array}$ \\
\hline 6. ROCK & $\begin{array}{l}\text { Carbonate rock (167), soluble rock (37), impermeable rock (30), fractured } \\
\text { rock (29), sedimentary rock (26), host rock (17), silicate rock (16), } \\
\text { volcanic rock (16), bare rock (13), crystalline rock (11), karstified rock } \\
\text { (11), igneous rock (10), clastic rock (10), metamorphic rock (9), porous } \\
\text { rock (9), non-karstic rock (8), calcareous rock (7), permeable rock (7), } \\
\text { consolidated rock (6), impervious rock (6), non-limestone rock (5), } \\
\text { non-carbonate rock (5), carbonatic rock (5) }\end{array}$ \\
\hline 7. AQUIFER & $\begin{array}{l}\text { Karst aquifer (582), karstic aquifer (52), carbonate aquifer (47), limestone } \\
\text { aquifer (31), unconfined aquifer (28), coastal aquifer (24), fractured } \\
\text { aquifer (21), artesian aquifer (15), transboundary aquifer (14), porous } \\
\text { aquifer (11), deep aquifer (9), intergranular aquifer (7), granular aquifer } \\
\text { (6), alluvial aquifer (7), dolostone aquifer (6), rock aquifer (6), confined } \\
\text { aquifer (6), karstified aquifer (6), shallow aquifer (4), clastic aquifer (3) }\end{array}$ \\
\hline 8. POLJE & $\begin{array}{l}\text { Karst polje (62), border polje (10), open polje (10), small polje (10), large } \\
\text { polje (9), dinaric polje (8), structural polje (6), dry polje (5), high polje (4), } \\
\text { closed polje (3) }\end{array}$ \\
\hline 9. SPRING & $\begin{array}{l}\text { Karst spring (241), large spring (42), submarine spring (21), karstic } \\
\text { spring (18), thermal spring (16), big spring (15), hot spring (13), } \\
\text { intermittent spring (11), small spring (10), perennial spring (9), overflow } \\
\text { spring (9), coastal spring (8), artesian spring (7), temporary spring (6), } \\
\text { permanent spring (6), cave spring (6) }\end{array}$ \\
\hline 10. DOLINE & $\begin{array}{l}\text { Collapse doline (121), large doline (48), solution doline (28), alluvial } \\
\text { doline (16), small doline (13), karst doline (9), deep doline (7), collapsed } \\
\text { doline (6), compound doline (6), big doline (6), funnel-shaped doline (5) }\end{array}$ \\
\hline 11. RIVER & $\begin{array}{l}\text { Underground river (44), surface river (16), allogenic river (13), karst river } \\
\text { (11), large river (10), subterranean river (7), major river (7), sinking river } \\
\text { (5), small river (5), intermittent river (3) }\end{array}$ \\
\hline 12. FRACTURE & $\begin{array}{l}\text { Prominent fracture (25), single fracture (15), standard fracture (10), } \\
\text { discrete fracture (9), individual fracture (9), enlarged fracture ( } 8 \text {, fine } \\
\text { fracture (7), open fracture (7), matrix fracture (7), large fracture (6), } \\
\text { diffuse fracture (5), vertical fracture (5), wide fracture (5), horizontal } \\
\text { fracture (4) }\end{array}$ \\
\hline 13. SEDIMENT & $\begin{array}{l}\text { Clastic sediment (25), unconsolidated sediment (8), carbonate sediment } \\
\text { (8), Quaternary sediment (8), colluvial sediment (7), pelagic sediment (7), } \\
\text { Cretaceous sediment (7), lacustrine sediment (6), marine sediment (6), } \\
\text { cave sediment (6), allochthonous sediment (5), Neogene sediment (5), } \\
\text { alluvial sediment (5), impermeable sediment (5) }\end{array}$ \\
\hline 14. STREAM & $\begin{array}{l}\text { Surface stream (51), underground stream (33), cave stream (28), sinking } \\
\text { stream (13), large stream (10), small stream (8), allogenic stream (7), } \\
\text { subterranean stream (6), vadose stream (6), karst stream (5) }\end{array}$ \\
\hline 15. DISCHARGE & $\begin{array}{l}\text { Spring discharge (67), water discharge (17), groundwater discharge (12), } \\
\text { base-flow discharge (9), stream discharge (6), thermal discharge (5), } \\
\text { coastal discharge (4) }\end{array}$ \\
\hline
\end{tabular}




\begin{tabular}{|c|c|}
\hline 16. CONDUIT & $\begin{array}{l}\text { Karst conduit (84), large conduit (21), single conduit (17), solution } \\
\text { conduit (11), parallel conduit (10), phreatic conduit (10), major conduit } \\
\text { (9), underground conduit (8), low conduit (7), small conduit (6), } \\
\text { individual conduit (5), long conduit (5), deep conduit (5), high conduit } \\
\text { (5), saturated conduit (4), horizontal conduit (4), subsurface conduit (4) }\end{array}$ \\
\hline 17. LAKE & $\begin{array}{l}\text { Temporary lake (9), karst lake (9), permanent lake (7), small lake (7), } \\
\text { intermittent lake (5), large lake (5), seasonal lake (4), eutrophic lake (3) }\end{array}$ \\
\hline 18. RECHARGE & $\begin{array}{l}\text { Constant recharge (28), allogenic recharge (15), groundwater recharge } \\
(14) \text {, aquifer recharge (11), diffuse recharge (10), concentrated recharge } \\
\text { (9), autogenic recharge (8), transient recharge (6), karst recharge (5), } \\
\text { rapid recharge (3) }\end{array}$ \\
\hline 19. DISSOLUTION & $\begin{array}{l}\text { Carbonate dissolution (10), calcite dissolution (8), limestone dissolution } \\
\text { (8), rock dissolution (4) }\end{array}$ \\
\hline 20. FORMATION & $\begin{array}{l}\text { Cave formation (39), rock formation (16), karst formation (16), limestone } \\
\text { formation (14), doline formation (12), carbonate formation (11), } \\
\text { geological formation (10), karstified formation (8), low permeability } \\
\text { formation (6), cavern formation (5), uvala formation (5), permeable } \\
\text { formation (4), sinkhole formation (3), surface formation (3) }\end{array}$ \\
\hline 21. PASSAGE & $\begin{array}{l}\text { Cave passage (94), vadose passage (22), phreatic passage (18), } \\
\text { underground passage (9), narrow passage (8), paragenetic passage (7), } \\
\text { large passage (6), horizontal passage (5), active passage (5), conduit } \\
\text { passage (5), alleviated passage (4), subterranean passage (3), vertical } \\
\text { passage (3), high passage (3) }\end{array}$ \\
\hline 22. UVALA & Large uvala (4), small uvala (3), compound uvala (3) \\
\hline 23. CALCITE & $\begin{array}{l}\text { Sparry calcite (7), magnesium calcite (7), red calcite (4), crystalline } \\
\text { calcite (3), hydrothermal calcite (3) }\end{array}$ \\
\hline 24. BASIN & $\begin{array}{l}\text { Karst basin (55), drainage basin (46), river basin (18), closed basin (14), } \\
\text { lake basin (13), groundwater basin (11), small basin (10), large basin (8), } \\
\text { solution basin (8), water basin (8), sedimentary basin (7), allogenic basin } \\
\text { (7), polje basin (7), shallow basin (6) }\end{array}$ \\
\hline 25. PRECIPITATION & $\begin{array}{l}\text { Annual precipitation (11), meteoric precipitation (9), local precipitation } \\
\text { (8), calcite precipitation (7), carbonate precipitation (5), intensive } \\
\text { precipitation (4), abundant precipitation (4), hourly precipitation (3), } \\
\text { daily precipitation (3) }\end{array}$ \\
\hline 26. SINKHOLE & $\begin{array}{l}\text { Large sinkhole (13), collapse sinkhole (7), small sinkhole (7), compound } \\
\text { sinkhole (3), karst sinkhole (3) }\end{array}$ \\
\hline 27. JOINT & $\begin{array}{l}\text { Enlarged joint (10), master joint (9), vertical joint (8), tectonic joint (4), } \\
\text { major joint (4), subvertical joint (3) }\end{array}$ \\
\hline 28. POROSITY & $\begin{array}{l}\text { Effective porosity (19), secondary porosity (17), matrix porosity (14), } \\
\text { primary porosity (11), high porosity (11), low porosity (9), efficient } \\
\text { porosity (5), fracture porosity (5), conduit porosity (5), dual porosity (4) }\end{array}$ \\
\hline 29. PERMEABILITY & $\begin{array}{l}\text { High permeability (19), low permeability (14), primary permeability (6), } \\
\text { matrix permeability (6), fracture permeability (4) }\end{array}$ \\
\hline 30. CAVITY & $\begin{array}{l}\text { Karst cavity (18), solution cavity (14), underground cavity (12), natural } \\
\text { cavity (11), large cavity (9), deep cavity ( } 7) \text {, subsurface cavity (6), small } \\
\text { cavity (5), spherical cavity (4), open cavity (4), subterranean cavity (3) }\end{array}$ \\
\hline 31. INFILTRATION & $\begin{array}{l}\text { Concentrated infiltration (32), diffuse infiltration (18), rapid infiltration } \\
\text { (10), direct infiltration (8), effective infiltration (3), efficient infiltration } \\
\text { (3) }\end{array}$ \\
\hline 32. KARSTIFICATION & $\begin{array}{l}\text { Hydrothermal karstification (11), functional karstification (6), epigene } \\
\text { karstification (5), early karstification (4), intense karstification (3) }\end{array}$ \\
\hline 33. LAYER & $\begin{array}{l}\text { Impermeable layer (15), thick layer (14), boundary layer (13), rock layer } \\
\text { (8), epikarst layer (7), soil layer (7), thin layer (6), diffusion layer (5), } \\
\text { permeable layer (5), gypsum layer (4), horizontal layer (4), limestone layer } \\
\text { (4), impervious layer (4), underground layer (3), surface layer (3) }\end{array}$ \\
\hline 34. FAULT & Regional fault (8), local fault (6), small fault (5), fracture fault (5) \\
\hline
\end{tabular}




\begin{tabular}{|c|c|}
\hline 35. CORROSION & $\begin{array}{l}\text { Mixture corrosion (21), lateral corrosion (6), alluvial corrosion (3), karst } \\
\text { corrosion (3) }\end{array}$ \\
\hline 36. DEPRESSION & $\begin{array}{l}\text { Karst depression (98), closed depression (75), large depression (39), } \\
\text { surface depression (18), small depression (16), shallow depression (8), } \\
\text { topographic depression (7), polje depression (7), big depression (5), } \\
\text { karstic depression (5), sinkhole depression (5), irregular depression (4), } \\
\text { deep depression (4), compound depression (3), circular depression (3) }\end{array}$ \\
\hline 37. KARSTIC & $\begin{array}{l}\text { Karstic aquifer (52), karstic system (20), karstic spring (18), karstic area } \\
\text { (15), karstic process (10), karstic uvala (9), karstic drainage (8), karstic } \\
\text { terrain (7), karstic erosion (6), karstic rock (6), karstic landform (5), } \\
\text { karstic evolution (5), karstic depression (5), karstic water (5), karstic } \\
\text { surface (4), karstic medium (3), karstic component (3) }\end{array}$ \\
\hline 38. TECTONIC & $\begin{array}{l}\text { Tectonic movement (21), tectonic activity (13), tectonic line (13), tectonic } \\
\text { structure (13), tectonic unit (8), tectonic uplift (8), tectonic stress ( } 7) \text {, } \\
\text { tectonic evolution (5), tectonic breccia (4), tectonic joint (4), tectonic } \\
\text { subsidence (4) }\end{array}$ \\
\hline 39. VADOSE & $\begin{array}{l}\text { Vadose zone (60), vadose passage (22), vadose flow (15), vadose cave (9), } \\
\text { vadose notch (8), vadose water (8), vadose environment (7), vadose } \\
\text { canyon (6), vadose stream (6), vadose shaft (3), vadose solution (3) }\end{array}$ \\
\hline 40. PHREATIC & $\begin{array}{l}\text { Phreatic zone (34), phreatic passage (18), phreatic environment (14), } \\
\text { phreatic loop (13), phreatic cave (9), phreatic flow (8), phreatic tube (7), } \\
\text { phreatic channel (4), phreatic system (3), phreatic water (3) }\end{array}$ \\
\hline 41. ALLOGENIC & $\begin{array}{l}\text { Allogenic recharge (15), allogenic valley (14), allogenic river (13), } \\
\text { allogenic drainage ( } 7) \text {, allogenic basin (7), allogenic stream (7), allogenic } \\
\text { water (7), allogenic erosion (5) }\end{array}$ \\
\hline 42. ALLUVIAL & $\begin{array}{l}\text { Alluvial doline (16), alluvial notch (12), alluvial plain (7), alluvial aquifer } \\
\text { (7), alluvial deposit (6), alluvial material (5), alluvial sediment (5), } \\
\text { alluvial fan (4), alluvial corrosion (3) }\end{array}$ \\
\hline 43. CALCAREOUS & $\begin{array}{l}\text { Calcareous rock (7), calcareous algae (6), calcareous deposit (6), } \\
\text { calcareous massif (5), calcareous sandstone (4) }\end{array}$ \\
\hline 44. ARTESIAN & $\begin{array}{l}\text { Artesian aquifer (15), artesian well (7), artesian spring (7), artesian flow } \\
\text { (6), artesian basin (3) }\end{array}$ \\
\hline 45. UNCONFINED & Unconfined aquifer (28) \\
\hline 46. CLASTIC & $\begin{array}{l}\text { Clastic sediment (25), clastic rock (10), clastic deposit (6), clastic aquifer } \\
\text { (3) }\end{array}$ \\
\hline 47. FLUVIAL & $\begin{array}{l}\text { Fluvial process (17), fluvial erosion (16), fluvial system (10), fluvial } \\
\text { sediment (9), fluvial valley (9), fluvial landscape (5), fluvial relief (5), } \\
\text { fluvial landform (4), fluvial karst (3) }\end{array}$ \\
\hline 48. SUBTERRANEAN & $\begin{array}{l}\text { Subterranean river (7), subterranean water (7), subterranean stream (6), } \\
\text { subterranean cavity (3), subterranean channel (3), subterranean drainage } \\
\text { (3), subterranean passage (3) }\end{array}$ \\
\hline 49. IMPERMEABLE & $\begin{array}{l}\text { Impermeable rock (30), impermeable bed (19), impermeable layer (15), } \\
\text { impermeable material (6), impermeable sediment (5) }\end{array}$ \\
\hline
\end{tabular}

